Jurnal Ilmu Dan Teknologi Kesehatan

Vol 8, No 2, March 2021,

ISSN: 2338-9095 (Print)

ISSN: 2338-9109 (online)

\title{
Effect of Cervical Cancer Early Detection Video on Increasing Women's Knowledge
}

\author{
Niken Purbowati, Junengsih, Niki Rian Putri, Aticeh \\ Poltekkes Kemenkes Jakarta III, Indonesisa \\ Email: purbowatiniken@gmail.com
}

\author{
Article history \\ Posted, June 18th, 2020 \\ Reviewed, Jan 15th, 2021 \\ Received, March 1st, 2021
}

\begin{abstract}
Efforts to increase the knowledge of women of childbearing age in preventing cervical cancer, one of the efforts made with health education. The lack of knowledge and awareness of women to detect cervical cancer early because it has not been exposed to information about this. Pasar Baru Village area the lowest coverage of cervical cancer early detection in Tangerang City, by 17\% compared to other regions. This research aims to know the effect of cervical cancer early detection video on increasing women's knowledge in the Pasar Baru Village District Karawaci Tangerang City. Quasi-experimental research pre-post-test with control group design. The data were analyzed using paired t-test and an independent t-test. The knowledge average scores comparison between pre-post-test scores for the treatment group $(56,39 \pm 7.12, p=0,0001)$ was higher than the control group $(36,81 \pm 7.18$, $p=0,0001)$. Post-test measurement showed a meaningful difference in average knowledge score between the treatment group and the control group $(p=0,0001)$, with a mean difference of 18.485. Video interventions are more effective at improving women's early detection of cervical cancer than lecture methods.
\end{abstract}

Keywords: cervical cancer; early detection; video

\begin{abstract}
ABSTRAK
Upaya untuk meningkatkan pengetahuan wanita usia subur (WUS) dalam mencegah kanker serviks, salah satu upaya dengan pendidikan kesehatan. Rendahnya pengetahuan dan kesadaran wanita untuk melakukan deteksi dini kanker serviks, karena belum terpaparnya informasi mengenai hal ini. Wilayah Kelurahan Pasar Baru paling rendah cakupan deteksi dini canker serviks di Kota Tangerang, sebesar 17\% dibandingkan wilayah lain. Tujuan penelitian ini bertujuan untuk mengetahui pengaruh video deteksi dini kanker serviks terhadap peningkatan pengetahuan wanita di Kelurahan Pasar Baru Kecamatan Karawaci Kota Tangerang. Penelitian quasi eksperiment pre test-post test with control group design. Data dianalisis menggunakan paired $t$ test dan independent $t$ test. Hasil penelitian menunjukkan perbandingan skor rerata pengetahuan antara skor pre-post-test untuk
\end{abstract}


kelompok perlakuan $(56,39 \pm 7,12, \mathrm{p}=0,0001)$ lebih tinggi dibandingkan kelompok kontrol $(36,81 \pm 7,18, \mathrm{p}=0,0001)$. Pada pengukuran post-test menunjukkan bahwa ada perbedaan rerata skor pengetahuan yang bermakna antara kelompok perlakuan dan kelompok kontrol $(\mathrm{p}=0,0001)$, dengan mean difference 18,485. Pemberian intervensi video lebih efektif meningkatkan pengetahuan wanita dalam deteksi dini kanker serviks dibandingkan metode ceramah.

Kata kunci: kanker serviks; deteksi dini; video

\section{INTRODUCTION}

Based on GLOBOCAN (2018), cervical cancer in Indonesia ranks second out of 5 most cancers at $10.48 \%$, with an estimated number of cervical cancer incidents 32,469 cases. Cervical cancer, the number 3 cause of death after heart disease and breast cancer, is $10.12 \%$, with a mortality rate of 18,278 cases. Data in Indonesia, early detection of cervical and breast cancer has been carried out on 3,040,116 women aged 30-50 years $(2.98 \%)$ (Kemenkes, 2018). Cervical cancer is a malignancy originating from the cervix. The cervix is the lower third of the uterus, cylindrical, protruding, and associated with the vagina through the external uterine ostium (KPKN; Kemenkes, 2017). In 2010 the estimated number of cervical cancer incidents was 454,000 cases (KPKN; Kemenkes, 2017). Around 200,000 cervical cancer-related deaths were found, and 46,000 of them were women aged 1549 who lived in developing countries (ESGO, 2011).
According to current estimates of the Indonesian Ministry of Health, the number of women with new cervical cancer ranges from 90-100 cases per 100,000, and 40 thousand cervical cancer cases occur annually. Cervical cancer events will significantly affect the lives of sufferers and their families and significantly affect the government's health financing sector. Therefore, increasing efforts to treat cervical cancer, especially in the field of prevention and early detection, are needed (Kemenkes, 2018). Early detection is done to find risk factors for non-communicable diseases as early as possible to individuals or groups at risk or not at risk routinely (Ministry of Health Republic of Indonesia, 2018). Screening aims to detect precancerous changes, which, if left untreated, can cause cancer. WHO recommends a comprehensive approach to preventing and controlling cervical cancer throughout a woman's life cycle (WHO, 2018). 
According to the Indonesian Health Profile, early detection of cervical and breast cancer has been carried out on $3.40,116$ women aged $30-50$ years $(2.98 \%)$ in Indonesia. The highest coverage of cervical and breast cancer detection in women aged $30-50$ is highest in the Bangka Belitung Islands at $13.19 \%$, followed by West Sumatra at $9.34 \%$, and South Kalimantan 8.77\%. Banten Province is ranked 31 out of 34 provinces in Indonesia, amounting to $1.11 \%$. The results of early detection of cervical cancer in Indonesia have found 105,418 positive IVAs, and 3,601 suspicious of cervical cancer (Kemenkes, 2018). Based on the results, health education using multi-media films effectively creates awareness and increases the knowledge and perceptions of adult women about cervical cancer and screening. Increased knowledge and awareness of women for early detection are essential for cervical cancer prevention programs (Abiodun et al., 2014).

Audiovisual aids such as video help stimulate the senses of hearing and vision so that the audience more easily receives and understands the speaker's message. Video media has several objectives in the learning process, namely to be able to clarify and facilitate the delivery of messages, overcome the limitations of time, space, and senses, can be used appropriately and varied (Abudukadeer et al., 2015), (Ochoa et al., 2020). Lack of knowledge and participation of women of childbearing age in carrying out early detection of cervical cancer due to lack of information sources. Based on this, the author is interested in researching the title "The Effect of Early Detection Cervical Cancer Video Media on Increasing Knowledge of Fertile Age Women (WUS) in PasarBaru Urban Village, Tangerang City. This research article is original and not plagiarism from the previous article.

\section{METHOD}

Quantitative research uses a quasiexperimental design with a pre-post-test with a control group design approach. In this study, research subjects were grouped into two groups: the treatment and control groups. The treatment group and the control group were both taken pre-post-test measurements of the knowledge of women of childbearing age in the early detection of cervical cancer. Only the treatment group was given an intervention media for the early detection of cervical cancer. In contrast, the control group was not given an intervention, only given information about cervical cancer by the lecture method. This study's population was all 
women of childbearing age in the Pasar Baru Village area of Tangerang City.

The sample size was 66 women of childbearing age, consisting of a control group and a treatment group. The sample in the treatment group and control group, namely women of childbearing age, have not been exposed to early detection of cervical cancer. Sampling is done by a randomized assignment sampling method. Respondents were randomly taken for the treatment groups in RW 1, 2, and 3, while the control group respondents in RW 4 and 5 in PasarBaru Village TangerangCity fulfilled the sample inclusion criteria.
This research has passed the Health Research Ethics Commission of Jakarta III Health Polytechnic's ethical clearance with the number KEPK-PKKJ3/176/IV/2019. This research instrument uses knowledge questionnaires and video media to deliver health education about early detection of cervical cancer. The pre-post-test data of two groups of pairs in the treatment group and the control group were analyzed using the paired t-test parametric test because the data were normally distributed. For the pre-post-test data, the two groups were not paired between the treatment and control groups because they met the normality of data requirements. The data were analyzed using the Independent t-Test.

\section{RESULTS AND DISCUSSION}

Table 1. Socio-Demographic Characteristic of Respondents

\begin{tabular}{lcccc}
\hline \multicolumn{1}{c}{ Variable } & \multicolumn{2}{c}{ Treatment Group } & \multicolumn{2}{c}{ Control Group } \\
& n & $\mathbf{\%}$ & n & $\mathbf{\%}$ \\
\hline Age & & & & \\
$\quad$ <20 years old & 1 & 3,0 & - & - \\
20-35 years old & 12 & 36,4 & 13 & 39,4 \\
$\quad>35$ years old & 20 & 60,6 & 20 & 60,6 \\
Total & 33 & 100 & 33 & 100 \\
\hline & & & & \\
Education & 9 & 27,3 & 11 & 33,3 \\
$\quad$ Low & 24 & 72,7 & 22 & 66,7 \\
$\quad$ High & 33 & 100 & 33 & 100 \\
Total & & & & \\
$\quad \begin{array}{l}\text { Profession } \\
\text { Does not work }\end{array}$ & 22 & 66,7 & 26 & 78,8 \\
$\quad$ Work & 11 & 33,3 & 7 & 21,2 \\
Total & 33 & 100 & 33 & 100 \\
\hline
\end{tabular}


Table 1 shows the socio-demographic characteristics of the respondents in both the treatment and control groups. Of 33 women of childbearing age in the treatment group, there was only one woman with an age category of fewer than 20 years, there were 12 women with an age category of 20 to 35 years, while 20 women with an age of more than 35 years. Women of childbearing age in the control group, the majority in the age category over 35 years, namely 20 women, with the age category of 20 to 35 years there are 13 women. For the education category, women of childbearing age in the treatment group were mainly highly educated. There were 24 women, while those with low education were nine women. Likewise, in the control group, most women of childbearing age with high education were 22 women, while with low education, there were 11 women. Most women of childbearing age in the treatment group did not work. In the control group, most women of childbearing age did not work. This study's results are the same as the previous study (Fridayanti \& Laksono, 2017), show that the effectiveness of health promotion with motivation by community leaders towards knowledge, attitudes, and behavior. As indicated on data analysis results, the mean rank value is higher than health promotion with leaflets. It shows that the provision of information accompanied by the motivation of community leaders who become role models in healthy behavior by performing early detection of cervical cancer using IVA tests is very influential on changes in knowledge, attitudes, and behavior. Besides that, the culture of Indonesian people, when they want to make a behavior change, there must be an example and encourage it so that the behavior change can be appropriately realized. The increase in better knowledge in this study confirms that knowledge is influenced by several factors, namely, age, gender, intelligence, and external factors, including education, mass media exposure, economics, social relations, and experience. There is exposure to the media or information sources, namely appropriate leaflets about cervical cancer and IVA tests, to better educate women about cervical cancer prevention. 
Table 2. Distribution of Pre-Post Test Knowledge Frequency in Treatment and Control Groups

\begin{tabular}{ccccc}
\hline Group & Mean & SD & Min - Max & 95\% CI \\
\hline Treatment & & & & \\
Pre test & 26,45 & 3,02 & $20-30$ & $25,38-27,53$ \\
Post test & 82,85 & 7,51 & $65-97$ & $80,18-85,51$ \\
& & & & \\
Control & & & $20-40$ & $25,75-29,34$ \\
Pre test & 27,55 & 5.05 & $49-78$ & $61,70-67,03$ \\
Post test & 64,36 & 7,51 & & \\
\hline
\end{tabular}

Table 2 shows that in the treatment group, the average score of knowledge of women of childbearing age in the early detection of cervical cancer during pre-test measurements was 26.45, lower than the post-test measurements of 82.85. The knowledge score of women of childbearing age at the lowest post-test measurements was 65 , and the highest was 97. The treatment group's knowledge score was higher than the control group after the video intervention was given for early detection of cervical cancer. In the control group, the average score of knowledge of women of childbearing age in the early detection of cervical cancer when the pretest measurement was 27.55 lower than the post-test measurement of 64.36. The knowledge score of women of childbearing age at the lowest post-test measurements was 49 , and the highest was 78. The post-test scores of maternal knowledge in early detection of cervical cancer in the control group were lower than in the treatment group because no video intervention was given, only lectures about early detection of cervical cancer.

The results of this study are the same as previous study (Sukamti, 2013), (Abiodun et al., 2014), (Ebu et al., 2019), there is an increase in good knowledge about early detection of cervical cancer from good perceptions about early detection of cervical cancer there is an increase from the pre-test measurement. The statistical test shows significant differences in knowledge, attitudes, and practices between the treatment and control groups after health education interventions using films about cancer and early detection of cervical cancer. Through films, multiple health education media have proven to be effective in raising awareness and increasing knowledge and perceptions about the early detection of cervical cancer. This film media is proven to increase knowledge about risk factors, 
symptoms, and efforts to prevent cervical

cancer.

Table 3. The Effect of Cervical Cancer Early Detection Videos on Pre-Post-Test Knowledge Scores in Treatment Groups and Control Groups

\begin{tabular}{llccccc}
\hline Group & & n & Mean \pm SD & $\begin{array}{c}\text { Mean Difference } \pm \\
\text { SD }\end{array}$ & 95\% CI & P \\
\hline Treatment & Pre-test & 33 & $26,45 \pm 3,02$ & $56,39 \pm 7,12$ & $58,92-$ & $0,0001^{*}$ \\
& & & & & 53,86 & \\
& Post-test & 33 & $82,85 \pm 7,51$ & & & \\
\hline Control & Pre test & 33 & $27,55 \pm 5,05$ & $36,81 \pm 7,18$ & $39,36-$ & $0,0001^{*}$ \\
& Post-test & 33 & $64,36 \pm 7,51$ & & 34,27 & \\
\hline very significat & using paired & & & &
\end{tabular}

*very significant using paired sample t-test

Table 3 shows that in the treatment group, the average knowledge score on women of childbearing age at pre-test was 26.45 with a standard deviation of 3.02. After being given video intervention for early detection of cervical cancer, there was an increase in the average score of knowledge of women of childbearing age at post-test, 82.85 with a standard deviation of 7.51. The difference in the average preposttest knowledge score of the treatment group was 56.39, with a standard deviation of 7.12. Statistical test results using a paired t-test showed a significant difference in knowledge in the pre-posttest measurement after video intervention was given to detect cervical cancer $(p=0.0001)$. In the control group, the average knowledge score of women of childbearing age at pre-test was 27.55 with a standard deviation of 5.05. There was an increase in the average post-test score of knowledge of women of childbearing age who were given information on early detection of cervical cancer using the lecture method, 64.36 with a standard deviation of 7.51. The average difference of the preposttest knowledge score of the control group was 36.81, with a standard deviation of 7.18. Statistical test results using paired t-test showed significant differences in knowledge in the preposttest measurements of the control group who were given information on early detection of cervical cancer using the lecture method $(\mathrm{p}=0.0001)$. Similarities in the methodology used can explain the findings observed. Comparing post-test scores for the intervention and control groups shows that health education interventions increase women's knowledge about 
cervical cancer screening. Even the pre and post-test scores for knowledge about cervical cancer screening in the control group show that there is a slight improvement in knowledge without intervention. Several factors are difficult to control when research is conducted in the community. Perhaps the respondent had read or received information about early detection of cervical cancer at the initial assessment (Ebu et al., 2019).

Table 4. The Effect of Cervical Cancer Early Detection Video on Women's Knowledge Score on Pre-test Measurements Between Treatment Group and Control group

\begin{tabular}{cccccc}
\hline Group & Measurement & n & Mean \pm SD & $\begin{array}{c}\text { Mean Difference (95\% } \\
\text { CI) }\end{array}$ & $\boldsymbol{p}$ \\
\hline Treatment & Pretest & 33 & $26,45 \pm 3,02$ & $1,091(0,96-3,14)$ & 0,292 \\
Control & & 33 & $27,55 \pm 5,05$ & & \\
\hline
\end{tabular}

Table 4 showed no difference in the average score of knowledge of women of childbearing age about early detection of cervical cancer between the treatment and control groups $(p=0.292)$. There was an average difference between the treatment group and the control group. The control group had a higher mean score of knowledge. It may have happened before, and have been exposed to information about cervical cancer. The results of this study are the same as the previous study. It showed that 154 women with cervical cancer at Jimma University Teaching Hospital in South Africa did not know about cervical cancer, knew the disease after being diagnosed at an advanced stage. Through microscopy, there were confirmed cancer cells in cervical squamous tissue. The common source of information and knowledge of women in the region is associated with low early detection rates of cervical cancer. In the future, research with interventions in the provision of health education using the media is expected to increase participation rates for early detection, which will reduce the incidence of cervical cancer (Saleem et al., 2019). Other empirical studies indicate that positive perceptions of cervical cancer screening in Egypt, Greece, and Nigeria have significantly increased after health education interventions. Therefore, the effect of providing health education interventions with media such as leaflets, videos, or films can be felt to increase knowledge and good perception of efforts to prevent cervical cancer by screening (Ahmed SR, Esa AS, 2018), (Mbachu et al., 2017). 
Table 5. The Effect of Cervical Cancer Early Detection Video on Women's Knowledge Scores on Post-test Measurements Between Treatment Group and

Control Groups

\begin{tabular}{cccccc}
\hline Group & Measurement & n & Mean \pm SD & $\begin{array}{c}\text { Mean Difference (95\% } \\
\text { CI) }\end{array}$ & $p$ \\
\hline Treatment & Posttest & 33 & $82,85 \pm 7,51$ & $18,485(22,17-14,79)$ & $0,0001^{*}$ \\
Control & & 33 & $64,36 \pm 7,51$ & &
\end{tabular}

Very significant independent samples $t$-test

Table 5 showed significant differences in mean knowledge scores between the groups of women of childbearing age who were given video interventions for early detection of cervical cancer and the control group that was only given information using the lecture method $(\mathrm{p}$ $=0.0001)$. Knowledge scores of women of childbearing age in the treatment group who were given a video intervention for early detection of cervical cancer were significantly higher than the control group who have only given the lecture the method, with a mean difference of 18,485 . Statistical tests prove video intervention to be more effective in increasing the knowledge of women of childbearing age in the early detection of cervical cancer than the lecture method.

This study indicates that there are significant differences in the knowledge of women of childbearing age about early detection of cervical cancer in the pre-post-test measurements between the treatment and control groups. There was an increase in knowledge scores for prepost-test measurements in women of childbearing age in the treatment group after being given a video intervention about early detection of cervical cancer. The increase in this treatment group's knowledge score was significantly higher than the control group, which was only given information on the early detection of cervical cancer by the lecture method. Video health education media has proven to be more effective in increasing knowledge about early detection of cervical cancer, visual acetate inspection (IVA test), and Pap Smear tests than the lecture method. Health education interventions are critical in increasing knowledge and perception and increasing women's self-efficacy about cervical cancer and early detection. The same study was also found in Jamaica. Women in the treatment group who were given health education interventions 
experienced increased knowledge about the risks, signs, and symptoms of preventing cervical cancer (Interis, 2015), (Kim, 2016). This study's results are the same as the previous study in Egypt showed that health education interventions had an impact on knowledge about cervical cancer screening. The mean score of the intervention group's knowledge score was higher after the health education program intervention compared to the control group (Ahmed SR, Esa AS, 2018). Research in the Qassim region of Saudi Arabia shows that most female respondents have more moderate knowledge of cervical cancer than those with good knowledge. Women in the Qassim region have a moderate perception of cervical cancer but have a negative perception of cervical cancer screening. Health promotion is needed to use media to increase awareness of early detection of cervical cancer to eliminate negative perceptions (Alnafisah et al., 2019).

The effectiveness of health education using video media to increase the knowledge of women of childbearing age, shown in the results of statistical tests, the value of the mean difference is higher than health education by the lecture method. Statistical test results using independent t-test showed that the provision of health education information using video media influenced the increase in knowledge of women of childbearing age in the early detection of cancer compared to the lecture method. Audiovisual or video aids help stimulate the senses of hearing and vision so that the audience more easily receives and understands the speaker's message. Video media has several objectives in the learning process, namely to be able to clarify and facilitate the delivery of messages, overcome the limitations of time, space, and senses, can be used appropriately and varied (Ahmed SR, Esa AS, 2018), (Cooper et al., 2021). Visual media are considered to increase target understanding up to 3 times, while audiovisual or video media are rated to increase understanding of health education targets six times. Video is an intermediary media whose material and absorption through sight and hearing, thus building conditions that can make the audience able to obtain knowledge and skills (Cooper et al., 2021).

\section{CONCLUSION}

This study shows that early detection videos of cervical cancer contribute to 
increased knowledge in women. Knowledge scores of women of childbearing age in the treatment group who were given a video intervention for early detection of cervical cancer were significantly higher than those in the control group who were only given the lecture method. Video helps stimulate the senses of hearing a vision to be more receptive and understand the message conveyed. Video advantages make it easier to deliver messages so that they can be accepted more clearly. The video also overcomes the inherent time, space, and sensory power, so that respondents can understand the message conveyed better than the lecture method. This intervention utilized a free-of-charge, educational resource in the native language, specifically in audio and video format rather than only a written questionnaire to optimize participant understanding irrespective of patient literacy. Limitation includes voluntary participation and self-selection of women who were motivated to attend the screenand-treat. Women who would also benefit from our educational intervention by using video would not attend the initiative-driven, time-limited event.

\section{ACKNOWLEDGEMENT}

We would like to thank all the respondents who have contributed to the research. We also thank the head of the village and all Pasar BaruVillage District Karawaci Tangerang City employees, which have provided facilities and support for this research.

\section{REFERENCES}

Abiodun, O. A., Olu-abiodun, O. O., Sotunsa, J. O., \& Oluwole, F. A. (2014). Impact of a health education intervention on knowledge and perception of cervical cancer and cervical screening uptake among adult women in rural communities in Nigeria. BMC Public health, 14:814. DOI: $10.1186 / 1471-2458-$ 14-814.

Abudukadeer, A., Azam, S., Mutailipu, A. Z., Qun, L., Guilin, G., \& Mijiti, S. (2015). Knowledge and attitude of Uyghur women in Xinjiang province of China related to the prevention and early detection of cervical cancer. World journal of surgical oncology. 13, 110. DOI: https://doi.org/10.1186/s12957015-0531-8

Ahmed SR, Esa AS, M. E. O. (2018). Health belief model-based educational program about cervical cancer prevention on women knowledge and beliefs. Egyptian Nursing Journal, 15 (1), 39.

Alnafisah, R. A., Alsuhaibani, R. A., Alharbi, M. A., Alsohaibani, A. A., \& Ismai, A. A. (2019). Saudi 
women's knowledge and attitude toward cervical cancer screening, treatment, and prevention: A crosssectional study in Qassim Region (2018-2019). Asian Pacific Journal of Cancer Prevention, 20(10), 2965-2969.

https://doi.org/10.31557/APJCP.20 19.20.10.2965

Cooper, E. C., Maher, J. A., Naaseh, A., Crawford, E. W., Chinn, J. O., Runge, A. S., Lucas, A. N., Zezoff, D. C., Bera, K. R., Dinicu, A. I., White, K. M., Tewari, S. E., Hari, A., Bernstein, M., Chang, J., Ziogas, A., Pearre, D. C., \& Tewari, K. S. (2021). Implementation of human papillomavirus video education for women participating in mass cervical cancer screening in Tanzania. American Journal of Obstetrics and Gynecology, 224(1), 105.e1-105.e9. https://doi.org/10.1016/j.ajog.2020. 07.018

Ebu, N. I., Amissah-Essel, S., Asiedu, C., Akaba, S., \& Pereko, K. A. (2019). Impact of health education intervention on knowledge and perception of cervical cancer and screening for women in Ghana. BMC Public Health, 19(1), 1-11. https://doi.org/10.1186/s12889-

019-7867-x

ESGO. (2011). Algorithms for management of cervical cancer. European Society Gynecology Oncology (ESGO).

Fridayanti, W., \& Laksono, B. (2017). Keefektifan Promosi Kesehatan Terhadap Pengetahuan, Sikap dan Perilaku Tentang Tes IVA pada Wanita Usia 20-59 Tahun Abstrak. 2(2), 124-130.
GLOBOCAN. (2018). Estimated number of incident cases and deaths worldwide, both sexes, all ages. https://gco.iarc.fr/today/

Interis. (2015). Increasing cervical cancer awareness and screening in Jamaica: Effectiveness of a theorybased educational intervention. International Journal of Environmental Research and Public Health, 13 (1), 53.

Kemenkes. (2018). Profil Kesehatan Indonesia Tahun 2017. Kementerian Kesehatan Republik Indonesia.

Kim, H. W. (2016). The health beliefs of mothers about preventing cervical cancer and their intention to recommend the Pap test to their daughters: a cross-sectional survey. BMC Public Health, 1-11. https://doi.org/10.1186/s12889016-3037-6

KPKN Kemenkes. (2017). Panduan Penatalaksanaan Kanker Serviks. Komite Penanggulangan Kanker Indonesia (KPKN); Kementerian Kesehatan Republik Indonesia.

Mbachu, C., Dim, C., \& Ezeoke, U. (2017). Effects of peer health education on perception and practice of screening for cervical cancer among urban residential women in south-east Nigeria: A before and after study. $B M C$ Women's Health, 17(1), 1-8. https://doi.org/10.1186/s12905017-0399-6

Ochoa, C. Y., Murphy, S. T., Frank, L. B., \& Baezconde-Garbanati, L. A. (2020). Using a Culturally Tailored Narrative to Increase Cervical Cancer Detection Among Spanish- 
Speaking Mexican-American Women. In Journal of cancer education: the official journal of the American Association for Cancer Education (Vol. 35, Issue 4, pp. 736-742). https://doi.org/10.1007/s13187019-01521-6

Saleem, A., Bekele, A., Fitzpatrick, M. B., Mahmoud, E. A., Lin, A. W., Velasco, H. E., \& Rashed, M. M. (2019). Knowledge and awareness of cervical cancer in Southwestern Ethiopia is lacking: A descriptive analysis. PLoS ONE, 14(11), 1-11. https://doi.org/10.1371/journal.pon e.0215117

Sukamti, S. (2013). Pendidikan kesehatan dan deteksi dini kanker serviks melalui inspeksi visual asam asetat. Jurnal Ilmu Dan Teknologi Kesehatan, 1(1), 18-23. http://www.ejurnal.poltekkesjakart a3.ac.id/index.php/jitek/article/vie w/19

WHO. (2018). Human papillomavirus (HPV) and cervical cancer. World Health http://who.org.id 